\title{
ALICJI HALICKIEJ POETYCKA UTOPIA PEJZAŻU
}

\author{
Artur WINIARSKI (Konstancin)
}

Pośród artystek, pochodzących z Polski związanych z paryskim środowiskiem artystycznym pierwszej połowy XX wieku, miejsce przypadające Alicji Halickiej (1889-1974) ${ }^{1}$ było szczególne pod wieloma względami. Gruntowne wykształcenie, w tym znajomość języków obcych, wszechstronność zainteresowań artystycznych, a także związek z kubistą Ludwikiem Markusem², pozwoliły urodzonej w Krakowie artystce być bezpośrednim obserwatorem, a także uczestnikiem paryskiej awangardy artystycznej. Alicja Halicka przyjaźniła się z wieloma pierwszoplanowymi postaciami artystycznego i literackiego milieu Paryża, znała m.in.: Juana Grisa, Guillaume’a Apollinaire'a, Maxa Jacoba, Georgesa Braque'a, André Bretona, Maxa Ernsta, Tristana Tzarę oraz Jeana Arpa. Miała okazję poznać również członków grupy Bloomsbury ${ }^{3}$. W Stanach Zjednoczonych współpracowała z wybitnymi twórcami broadwayowskiego baletu m.in.: z Igorem Strawińskim oraz Georgesem Balanchine' em ${ }^{4}$.

${ }^{1}$ Dotychczasowe informacje dotyczące dat urodzin i śmierci artystki przekazywane były w literaturze w dwóch wersjach (1895-1975) lub też (1884-1975). Brak natomiast jest jakichkolwiek źródeł potwierdzających zasadność używania którejkolwiek z tych wersji. Zgodnie z najnowszymi badaniami, udokumentowanymi certyfikatem małżeństwa oraz potwierdzeniem zgonu, prawidłowe daty życia artystki to: 20 grudnia 1889 - 30 grudnia 1974.

${ }^{2}$ Markus znany później jako Marcoussis - pseudonim, którego artysta używał za namową Apollinaire'a.

${ }^{3}$ Znajomość z członkami grupy zapoczątkowana została poprzez Rogera Fry’a, przyjaciela Halickiej i Marcoussisa. Roger Fry był miłośnikiem francuskiej sztuki i poznał twórczość Halickiej na wystawie „French Art 1914-1919” zorganizowanej przez Leopolda Zborowskiego i Oswalda Sitwella w Mansard Gallery w 1919 roku. Halicka i Marcoussis poznali także krytyka Clive'a Bella. Pośród londyńskich znajomych znaleźli się również współtwórcy wortycyzmu m.in.: Wyndham Lewis i Ezra Pound, jak również prozaik i krytyk Ford Madox Ford i jego żona Stella Bowen.

${ }^{4}$ Współpraca Halickiej z kompozytorem Igorem Strawińskim oraz tancerzem i choreografem Georgesem Balanchine'em miała miejsce podczas pobytu Halickiej w Stanach Zjednoczonych w latach 1935-1938. Halicka projektowała dekoracje i kostiumy do baletu Igora Strawińskiego Pocatunek wieszczki (The Fairy's Kiss), którego premiera miała miejsce 27 kwietnia 1937 w The Old Metropolitan Opera House w Nowym Jorku. Poza tym Halicka wykonała także dekoracje do baletów: Ogród publiczny oraz Poślubiłam anioła. 
Niemożliwym jest podjęcie rozważań na temat twórczości pochodzącej z Krakowa artystki, pominąwszy kontekst osobisty, wszak to postać Louisa Marcoussisa wpłynęła na artystyczne wybory podejmowane przez Halicką. Z jednej strony związek z Marcoussisem otworzył Halickiej możliwość uczestniczenia w najważniejszych wydarzeniach tamtego czasu dzięki poznaniu wielu znakomitych osobistości świata literackiego i artystycznego, z drugiej zaś strony był pewnego rodzaju ograniczeniem dla ambitnej artystki. Obecnie przypuszcza się, iż Halicka właśnie przez silną osobowość artystyczną swojego męża nie mogła lub nie chciała w pełni realizować swoich zainteresowań malarstwem kubistycznym ${ }^{5}$ oraz rozwijać pracy nad grafiką warsztatową ${ }^{6}$.

Przyjąwszy taki punkt widzenia, w którym rozwój artystycznej kariery Halickiej podyktowany był czynnikami od niej niezależnymi, trudno nie dostrzec również jego pozytywnych następstw. Porzucając kubizm, Halicka szukała innych form realizacji własnego talentu. Niewykluczone, iż na kanwie tych poszukiwań artystka zainteresowała się projektowaniem tkanin, co w konsekwencji zaowocowało oryginalną serią tzw. wytłaczanych romansów wykonywanych w latach 20., lub wspomnianymi wyżej sukcesami w realizacjach scenicznych broadwayowskiego baletu.

To, co było cechą wspólną obojga małżonków Halickiej i Marcoussisa to z pewnością głębokie zainteresowania poezją. Nie bez znaczenia pozostaje fakt, iż młoda artystka przybyła z Krakowa była częstym gościem w domu Władysława Mickiewicza przy ulicy Guénégaud 7, gdzie kultywowana była tradycja poezji romantycznej. Oprócz Halickiej w poniedziałkowych spotkaniach w domu Mickiewicza brali udział m.in.: malarz Tadeusz Makowski, rzeźbiarz Edward Wittig oraz historyk literatury, krytyk i poeta Zygmunt Lubicz-Zaleski ${ }^{7}$.

Ponadto Halicka i Marcoussis często gościli w swoim domu poetę i teoretyka kubizmu Guillaume'a Apollinaire'a — poznanego przez Ludwika jeszcze w 1910 roku w cyrku Médrano. Apollinaire jadał obiady i kolacje w domu Marcoussisa i Halickiej, a wspólnie spędzone chwile stawały się okazją do dyskusji o poezji. Autor Alkoholi często nosił przy sobie tomik poezji, w którym ciągle zmieniał interpunkcję, i deklamował swoje wiersze. W swoich wspomnieniach Halicka opisywała wspólne spotkania, oddając nastrój panujący podczas recytacji wierszy przez Apollinaire’a:

Miał bardzo piękny głos i lubił deklamować wiersze w osobliwej pozie: siedząc przy-

klękał na jedno kolano, a brzuch wystawał mu $\mathrm{z}$ fotela ${ }^{8}$.

To właśnie tę cechę umiejętności poddania się poetyckiemu nastrojowi u Halickiej podkreślała Julia Hartwig, wywodząc ją wraz z pochodzeniem artystki z: „,młodopolskiego, oczadziałego od nastrojów Krakowa"”.

${ }^{5}$ Taką tezę przytaczają Krzysztof Zagrodzki oraz Paula J. Birnbaum za Jeanine Warnod; por.: K. Zagrodzki, Alicja Halicka: mistrzowie Ecole de Paris, [katalog wystawy]. Villa la Fleur w Konstancinie, 22 września-31 grudnia 2011, Warszawa 2011, s. 19; P. J. Birnbaum, Women Artists in Interwar France: Framing Femininities, Farnham-Burlington 2011, s. 142; por. także: J. Warnod, Alice Halicka et ses Souvenirs, Terre d'Europe 1974 nr 48, s. 3.

${ }^{6}$ Louis Marcoussis, był wziętym i uznanym grafikiem. Wiemy, iż Halicka uprawiała grafikę, a zwłaszcza akwafortę i litografię. Artystka nie kryła zadowolenia, iż o jej litografiach pochlebnie miał wyrażać się Henri Matisse, odwiedzając drukarnię Chatel, gdzie pracowała w latach 20.; por.: A. Halicka, Wczoraj, s. 111. Obecnie znanych jest kilka realizacji graficznych m.in. portrety Serge'a Lifara i René Crevela wykonane techniką akwaforty, czy też litografia przedstawiająca Plac Zgody w Paryżu (1955).

${ }^{7}$ A. Wierzbicka, We Francji i w Polsce 1900-1939, Warszawa 2009, s. 20.

${ }^{8}$ A. Halicka, Wczoraj: wspomnienia, autoryzowany przekł. W. Błońska, Kraków 1971, s. 55.

${ }^{9}$ J. Hartwig, Apollinaire, Warszawa 2010, s. 238. 
Umiejętność wydobycia nastroju, stanowiącego tak w poezji, jak i malarstwie środek dotarcia do istoty utworu, stała się także jedną z najważniejszych cech malarstwa Alicji Halickiej. Nastrojowość w jej obrazach budowana jest poprzez charakterystyczne zastosowanie środków formalnych, które w różnych etapach jej twórczości przejawiały się bądź to w kontrastowych zestawieniach czystych plam barwnych, bądź też drgającej szmaragdowej kolorystyce spowijającej pejzaże paryskie. Celna charakterystyka owej poetyckości malarstwa Halickiej była przedmiotem komentarza w „The American Magazin of Art":

Sztukę Halickiej cechuje umiejętność tworzenia swej wizji poetyckiej w oparciu o precyzyjny rysunek, precyzyjny i zwięzły przy jednoczesnej tendencji do chwytania przelotnego momentu - ona to tak wyjaśnia: istotę przedmiotu osiąga się nie przez konkretność obiektu, a raczej przez nastrój. W swych obrazach z Placu Zgody w Paryżu osiągnęła ona właśnie tę przemijającą i zmienną atmosferę. Mityczne rżące konie, heroldowie i boginie, fragmenty bram żelaznych, obelisk, odległy Crillon, przypadkowo napotkane składane krzesła stały się luźnymi symbolami zespolonymi nastrojem, $\mathrm{w}$ momencie spotkania się jej inteligencji z nastrojem południa czy pachnącej lawendą nocy na Placu Zgody ${ }^{10}$.

Te dążenia Halickiej zauważali krytycy sztuki dość wcześnie, bo w latach 20. XX wieku. Waldemar George postrzegał jej malarstwo jako pewnego rodzaju ars poetica, podkreślał również liryzm w jej twórczości:

Paryż odkrył Alicję Halicką bardzo niedawno. Wszechstronna ta artystka jest przede wszystkim poetką. Środki ekspresji, którymi włada, dobór kolorów, rysunek falisty, nerwowy, chwilami abstrakcyjny, a czasami realistyczny, wskazuje, że jej artystyczny światopogląd jest na wskroś liryczny [...] Alicja Halicka podkreśla, podnosi i egzaltuje wygląd swoich obrazów dzięki swym odkryciom poetycznym, które jej pozwalają prawie że równocześnie wydobyć i podkreślić sens wzruszeniowy i sens malarski przedmiotu $^{11}$.

Sama Halicka również przyznawała, iż kluczem do jej twórczości jest poetycki charakter malowanych przez nią obrazów. Literacki wymiar jej twórczości nie opierał się jednak na wykorzystaniu anegdoty. Obraz — według artystki — nie służył do przekazywania narracji, będąc niejako na usługach literatury, powinien się jednakże posługiwać środkami właściwymi dla dzieła poetyckiego w sferze formalnej. W jednym $\mathrm{z}$ wywiadów artystka tak mówiła o roli poezji w jej sztuce:

Nie jestem ani kubistką, ani naturalistką, ani impresjonistką, ani surrealistką. Po prostu pragnę wyrażać poetyckość i chcę, żeby wynikała nie z literatury, nie z tematu, ale $\mathrm{z}$ treści plastycznej obrazu ${ }^{12}$.

Obrazy Halickiej emanują poetyckim nastrojem nie tylko w warstwie formalnej, czy też wynikają, jak chciałaby artystka, jedynie z „treści plastycznej”. Ważna jest także, o czym Halicka nie wspomina w przytoczonym fragmencie wywiadu, tematyka obrazu.

Jednym z bardziej żywotnych tematów w sztuce Alicji Halickiej był pejzaż, a zwłaszcza pejzaż miejski. Halicka przejawiała wyjątkową dociekliwość w obserwacji miasta jako żywego organizmu. Wiązało się to z pewnego rodzaju świeżością spojrzenia na

\footnotetext{
${ }^{10}$ Cyt. za: Wystawa malarstwa Alicji Halickiej (Paryż), [katalog wystawy], przedm. J. Cassou. Związek Polskich Artystów Plastyków, Centralne Biuro Wystaw Artystycznych, Warszawa 1956 , s. 8.

${ }^{11}$ [J. W. Jarociński] Waldemar George, Sylwety artystyczne, Pani 1924 nr 1-2, s. 30-31.

${ }^{12}$ H. Kowzan, Baśń barw: letni wieczór w Tuileries, Świat $1956 \mathrm{nr} 41$, s. 10.
} 
rozwój miasta, jego historię, architekturę i symbolikę. W tych malarskich zapiskach, nie zabrakło także miejsca na osobisty stosunek uczuciowy artystki do ,portretowanych” miejsc.

\section{Rozwój pejzażu w twórczości Alicji Halickiej}

Stosunkowo niewiele wiemy o malarskich zainteresowaniach Halickiej z okresu studiów w Szkole Sztuk Pięknych dla Kobiet Marii Niedzielskiej w Krakowie, czy też jej pobytu w Monachium. Nie znamy jej obrazów z tamtego czasu. Sama artystka również nie wspomina nic o tematach jej malarskich zainteresowań. Wiadomo jednak, iż od lat dziecięcych przejawiała zainteresowanie rzeźbą miejską. Jako mała dziewczynka zachwycała się rzeźbą, głównie zaś fontannami oraz elementami miejskiej architektury. Nie bez znaczenia pozostaje fakt, iż po kilkudziesięciu latach Halicka przywołała wspomnienia z dzieciństwa, w których podziwiała piękno wiedeńskiej architektury i rzeźby:

Mijałyśmy barokowe fontanny, morskie potwory pluły wodą u stóp kamiennych bogiń.

W „Volksgarten” Medea rozpaczała nad trupami swych pomordowanych dzieci. Z dachu Parlamentu ulatywały kwadrygi z brązu ${ }^{13}$.

W latach 30. Halicka powróci do zaklętej w kamieniu mitologii i uczyni ją jednym $\mathrm{z}$ naczelnych tematów swojego malarstwa.

W pierwszych latach po przyjeździe do Paryża, Halicka nie przejawia zainteresowania pejzażem w swoim malarstwie. Gros przedstawień stanowią wtedy martwe natury, portrety oraz sceny rodzajowe. W tej tematyce artystka podejmuje zagadnienia zbieżne z poszukiwaniami kubistów, a mianowicie dotyczące konstruowania przestrzeni w obrazie obrazu oraz jego kompozycji. Do tych zagadnień sukcesywnie Halicka włącza również problem koloru, jako ważnego czynnika kształtującego obraz.

Dopiero w serii gwaszy przywiezionych z krakowskiego Kazimierza w latach 1919 i 1921 oraz na obrazach olejnych o podobnej tematyce, pojawia się przestrzeń miejska. Wówczas pejzaż jest jedynie tłem dla rozgrywających się scen.

Bardzo ważnym etapem w rozwoju pejzażu w malarstwie Halickiej były akwarele $\mathrm{z}$ początku lat 20. Spośród znanych prac z tego okresu warto wymienić dwie: Rue Lepic ulubioną uliczkę artystki ${ }^{14}$ oraz widok na Montmartre. W pracach tych zaznacza się echo kubistycznych doświadczeń artystki widoczne zwłaszcza w zestawianiu poszczególnych „cytatów rzeczywistości” na zasadzie collage'u oraz podporządkowywaniu ich kompozycji całości. Zastosowanie takiej poetyki, było zabiegiem celowym, u podłoża którego leżała chęć uchwycenia substancji żyjącego miasta, jego temperamentu, dynamizmu oraz zmienności.

W latach 30. Halicka malowała głównie pejzaże Paryża. Najważniejszym, i niemalże obsesyjnym, tematem jej przedstawień stał się Plac Zgody. Jeden z bardziej znanych obrazów z tego cyklu pochodzi z 1933 roku i należy do zbiorów muzeum sztuki współczesnej w Paryżu (Musée national d'art moderne w Centre Georges Pompidou). W pejzażach paryskich, czy też nieco późniejszych nowojorskich dostrzegalne są wpływy innych artystów, a zwłaszcza Giorgio de Chirico i Jeana Dufy’ego. Halicka znała twórczość Chirico, oglądając chociażby obrazy tego artysty w kolekcji Paula

\footnotetext{
${ }^{13}$ A. Halicka, Wczoraj, s. 9.

14 „Uwielbiałam ulicę Lepic. Pełno tam było jarzyn i owoców po śmiesznie niskich cenach”; por.: tamże, s. 61 .
} 
Guillaume'a. Spotykała go także podczas swojego pobytu w Nowym Jorku ${ }^{15}$. W sztuce urodzonego w Grecji artysty, przejawiają się reminiscencje antycznej kultury, pewnego rodzaju tęsknota za nią. Halicka niewątpliwie eksplorowała antyczny topos. Plac Zgody był dla niej z pewnością swego rodzaju kontynuacją spuścizny antycznej. W swoich wspomnieniach przeciwstawiała architekturę Paryża zabudowie Nowego Jorku, widząc w tym mieście z kolei swoisty romantyzm:

Malowałam posągi Placu Zgody i jego cudowny architektoniczny klasycyzm, kontra-

stujący z wyuzdanym romantyzmem wielkiego amerykańskiego miasta ${ }^{16}$.

Nie tylko w tematyce, ale także w sferze formalnej dostrzec można pokrewieństwa z malarstwem Chirico, zwłaszcza w sposobie malowania koni, gdzie artystka posługuje się barwną wibrującą kreską. Halicka tworzy własne „muzeum wyobraźni” z obrazami łączącymi w sobie historię z teraźniejszością, poetycką wizję z realistycznym pejzażem. W obrazach tego muzeum artystka konstruuje przestrzeń miejską, której głównym bohaterem nie jest przewijający się tłum. W obrazach Halickiej miasto ożywiane jest swoją historią — haniebną lub triumfalną, mitologią drzemiącą w pomnikach miejskich fontann i mostów, czy wreszcie symbolami pustych krzeseł.

Zestawienia kolorystyczne w pejzażach z Nowego Jorku czy późniejsze pejzaże z Indii polegały na subtelnych dominantach błękitów lub też kontrastowych zestawieniach błękitów i czerwieni. Tego rodzaju efekty kolorystyczne sytuowały malarstwo pochodzącej z Krakowa artystki blisko twórczości Raoula, a zwłaszcza Jeana Dufy. Widoki Tuileries malowane technikami wodnymi, podkreślały swobodę wypowiedzi oraz wrażliwość i delikatność artystki.

W przedstawieniu Paryż $w$ Godzinie $G^{17}$ antyczny świat legnie w gruzach. Tragiczna w skutkach druga wojna światowa, przyniosła Halickiej-artystce wiele przykrych doświadczeń. Razem z Marcoussisem i córką musiała opuścić Paryż, osiadając najpierw w Vichy, a później w pobliskim Cusset ${ }^{18}$. Przedwczesna śmierć Marcoussisa w 1941 roku była dla Halickiej dodatkowym ciosem, otwierającym kolejny etap tułaczki, tym razem w Marsylii, Vienne, Chamonix, Sallanches.

W latach powojennych Halicka skupiała się prawie wyłącznie na malowaniu pejzaży miejskich. Obrazy powstające wówczas były pokłosiem podróży artystki do Indii, które odwiedziła w 1952 roku (owocem tej wyprawy był cykl Cuda Indii), Związku Radzieckiego oraz Polski, gdzie odbyła się jej wystawa w 1956 roku w warszawskiej Zachęcie. W pejzażu warszawskim Alicja Halicka również śledziła historię miasta zapisaną w jego pomnikach. Malowała między innymi Łazienki Królewskie oraz Stare Miasto. Najciekawszym obiektem pędzla Halickiej z tego czasu jest Widok na Stare Miasto z 1958 roku, (il. 22) obraz utrzymany w tonacjach zieleni — charakterystycznej kolorystyce dla późnego okresu twórczości artystki. Typowe dla Halickiej malarstwo zostało wpisane w kompozycję tradycyjnej weduty. Zastosowanie klasycznej kompozycji nie było naśladownictwem ${ }^{19}$, ale zabiegiem celowym. Artystka podkreślała tym

15 Tamże, s. 177.

16 Tamże, s. 257

17 Obraz z cyklu Godziny Paryża. Oryginalny tytuł z języka francuskiego brzmi Paris à l'Heure $H$, co można odczytywać jako nawiązanie do amerykańskiego określenia lądowania w Normandii jako D-Day.

18 Obie miejscowości położone w Owernii należały do tzw. wolnej strefy, utworzonej w wyniku zawieszenia broni podpisanego pomiędzy Niemcami i Francją 22 czerwca 1940 roku.

19 Przykładem, do którego Halicka mogła się odwoływać jest obraz Panorama Warszawy przypisywany Chrystianowi Melichowi, namalowany ok. 1625 roku i znajdujący się w Bayeri- 
samym znaczenie historii w dziejach miasta i zrozumienie tejże historii przez artystę. Obraz był dokumentacją heroicznego momentu w historii miasta, które podniosło się ze zgliszczy wojennych.

Jednym z ostatnich akordów twórczych Halickiej, był przedstawiany m.in. w warszawskiej Kordegardzie w 1968 roku cykl płócien pt. Bramy Paryża. W odróżnieniu od poprzednich pejzaży ukochanego miasta, artystka skupiała się na jego przedmieściach, wśród których pojawiły się przedstawienia La Rotonde de la Villette. Na innych pejzażach tego cyklu przed oczami widza piętrzyły się olbrzymie mury, bloki mieszkalne, a niekiedy fabryki i ich dymiące kominy. Odległa kraina heroicznych czasów młodości Alicji Halickiej i jej artystycznego otoczenia, której symbolami były wzgórze Montmartre i majestatyczna bazylika Sacré-Cœur, czy też Wieża Eiffle’a, zarysowywały się jedynie w tle industrialnego pejzażu „teraźniejszości”.

\section{ALICJA HALICKAS' ARTISTIC UTOPIA OF THE LANDSCAPE}

Alicja Halicka, one of the most important Polish-born female painters of the $20^{\text {th }}$ century, was a member of the French Avant-garde Movement. Along with her husband, the cubist painter Louis Marcoussis, Halicka was strongly influenced by modern poetry. In her art and particularly in landscapes she combines some fragments of the visual world with dreams, poetry and mythology. She observes towns and cities through their history and their monuments and sculptures.

KEY WORDS: Alicja Halicka; Louis Marcoussis; Guillaume Apollinaire; poetry; utopia; School of Paris; Ecole de Paris; Montmartre; Montparnasse; Igor Stravinsky; ballet; Georges Balanchine.

sche Staatsgemäldesammlungen w Monachium, którego kopia znajduje się w zbiorach Muzeum Historycznego Miasta Stołecznego Warszawy. 